\title{
Heavy Metal Contamination of Selected Vegetables from Crude Oil and Non Crude Oil-Producing States in Nigeria: A Comparative Study
}

\author{
M.A. Okonkwo ${ }^{1}$, U.A. Onyechi ${ }^{1}$, C.A. Anukwuorji ${ }^{2}$, P.C. Chukwunwe ${ }^{3}$, \\ J.C. Sopuru ${ }^{1}$ \\ ${ }^{1}$ Department of Human Nutrition And Dietetics, University Of Nigeria, Nsukka, \\ ${ }^{2}$ Department of Botany, Nnamdi Azikiwe University, P. M. B. 5025, Awka. Anambra State \\ ${ }^{3}$ Department of Animal Science, University of Nigeria, Nsukka \\ "dozygreat2k2@yahoo.co.uk
}

\begin{abstract}
Keywords: Heavy metals, Telfaria occidentialis, Talinum triangulare, Ocimium gratissimum, Murraya koenigii, River State, Enugu State.
\end{abstract}

\begin{abstract}
The aim of this study was to investigate and compare the heavy metal (HM) concentrations of selected vegetables harvested from crude oil-producing Rivers State and non-oilproducing Enugu State in Nigeria. Four vegetables; Telfaria occidentialis, Talinum triangulare, Ocimium gratissimum, and Murraya koenigii, were obtained from local farms in local government areas (LGAs) selected, each from the 3 senatorial zones in each state. The chemical analysis in $\mathrm{mg} / 100 \mathrm{~g}$ of the heavy metals (HMs) was conducted using standard methods. There mean values varied in the order: lead $(\mathrm{Pb})>$ cadmium $(\mathrm{Cd})>$ mercury $(\mathrm{Hg})$ in $\mathrm{mg} / 100 \mathrm{~g}$. Vegetable samples harvested from Rivers State had the highest toxicity level for both $\mathrm{Pb}(0.19$ to 0.34$)$ and $\mathrm{Hg}(0.01$ to $0.03)$, while samples harvested from Enugu State had the highest toxicity level for $\mathrm{Cd}(0.07$ to 0.25). The mean $\mathrm{Pb}$ contents for Ocimium gratissimum (0.27) and Talinum triangulare (0.26), harvested from Rivers States were significantly $(p<0.05)$ higher than their counterparts harvested from Enugu State (0.19 and 0.21, respectively). Mercury had the least mean value than $\mathrm{Pb}$ and $\mathrm{Cd}$ in all the locations. All the vegetables from all the localities in this study had toxic levels of HM much above the FAO/WHO acceptable limits; $0.03 \mathrm{mg} / 100 \mathrm{~g}$ for $\mathrm{Pb}$, and $0.02 \mathrm{mg} / 100 \mathrm{~g}$ for $\mathrm{Cd}$ in foods and $0.0001 \mathrm{mg} / 100 \mathrm{~g}$ for $\mathrm{Hg}$ in mineral water. It can therefore be said that the public health importance for increased consumption of fruits and vegetables may equally mean increased HM consumption and bioaccumulation for the population in Rivers and Enugu States.
\end{abstract}

\section{Introduction}

Environmental degradation has been a topical issue to the existence and survival of man for years. With the increased level of industrialization, many wastes are generated which leaves man exposed to heavy metal (HM) toxicity. Anthropogenic sources of heavy metal contamination come from industrial effluents, mining, fuel production, military operations, smelting processes and utilization of agricultural chemicals, brick kilns, small-scale industries and coal combustion [1]. In Nigeria, human activities such as industrialization, urbanization, agriculture, and extraction activities in the oil and gas sector, have led to incidences of environmental pollution [2]. These human activities on the environment lead to erosion, formation of sinkholes, loss of biodiversity, contamination of soil and contamination of water systems [3]. Some crops and cover plants growing in the disposal area may selectively take up heavy metals (HMs) [4] and other toxic substances to be passed up the food chain. Bioaccumulation is the net build-up of substances from water in an aquatic organism as a result of enhanced uptake and slow elimination of such substance [2]. HMs intake by human populations through the food chain has been reported in many countries. It is well known that poisonous HMs such as cadmium $(\mathrm{Cd})$, lead $(\mathrm{Pb})$, arsenic $(\mathrm{As})$, chromium $(\mathrm{Cr})$, and mercury $(\mathrm{Hg})$ have elevated levels of concentration around sites of petroleum exploration and production operations and promote the risk of cancer related illnesses [5]. 
Increased cancer risk is a common feature of chronic exposure to certain metals; the exact mechanism of their carcinogenicity is not completely understood, although many are weak mutagens (cause DNA damage), they can disrupt gene expression, deregulate cell growth and development [6]. They can also interfere with innate DNA repair systems [7]. Currently, plants or microorganisms are tentatively used to remove some heavy metals such as mercury. Plants which exhibit hyper accumulation can be used to remove heavy metals from soils by concentrating them in their biomatter [8].

Heavy Metals contamination of the food items is one of the most important aspects of food quality assurance [9]. Leafy vegetables grown on HM contaminated soils accumulate higher amounts of metals than those grown in uncontaminated soils because they absorb these metals through their roots [10]. [11] reported that vegetables accumulate considerable amount of HMs especially $\mathrm{Pb}, \mathrm{Cr}, \mathrm{Cd}$, and $\mathrm{Zn}$ in roots and leaves. [12] reported increased $\mathrm{Pb}$ uptake in the leaves of water leaf (Talinum triangulare), and okra fruits (Albemuscus esculentus). In the South-East region of Nigeria, domestic vegetable gardening is a common practice because green leafy vegetables constitute a major component of the diets and is of great economic value [13]. The main threats to human health from heavy metals are associated with exposure to lead, cadmium, mercury and arsenic as reported by [14]. Industries have largely been reported to be responsible for discharging pollutants containing heavy metals; $\mathrm{Zn}, \mathrm{Cu}, \mathrm{Mn}, \mathrm{Cd}, \mathrm{Ni}, \mathrm{Hg}, \mathrm{Pd}, \mathrm{Cr}, \mathrm{Fe}$ and $\mathrm{Co}$ into our environments [15]. The major heavy metal cases in Nigeria as reported by [6] were associated with lead poisoning, through inhalation.

The data collected from this study will serve as baseline information on the quality and safety condition of vegetables harvested from and consumed both in the oil-producing Rivers and non-oilproducing Enugu States, Nigeria. The result will be informative for carrying out nutrition education programs by nutritionists and will aid community development by making individuals and communities aware of HM pollution and toxicity and the need to minimize exposure. The findings can also go a long way to better the standard of living of the implicated regions if change agents; Government, Ministries of Environment and related bodies for environmental health address the environmental remediation of implicated communities.

Therefore the objectives of this study were to:

(i) determine the heavy metal $(\mathrm{HM})$ : lead $(\mathrm{Pb})$, cadmium $(\mathrm{Cd})$, and mercury $(\mathrm{Hg})$ contents of fluted pumpkin leaf (Telfaria occidentialis), waterleaf (Talinum triangulare), scent leaf (Ocimium gratissimum) and curry leaf (Murraya koenigii) plants harvested from local farms in communities of Eleme, Ogu/Bolo, Etche, and Ogba/Egbema/Ndoni LGAs of oil-producing Rivers State, as well as, in Nsukka, Aninri, and Enugu-South LGAs of non-oil-producing Enugu State

(ii) compare the varying levels of HM contents of the selected vegetables harvested from communities in LGAs in Rivers and Enugu, both within and between the States

(iii) compare the mean varying levels of the HM contents of the selected vegetables harvested from both States against the FAO/WHO recommended critical level in foods.

\section{Materials and Methods}

\section{Preparation of the vegetables}

A total of four vegetables; fluted pumpkin leaf (Telfaria occidentalis), waterleaf (Talinum triangulare), curry leaf (Murraya koenigii), and scent leaf (Ocimium gratissimum) were harvested where available from local farms in Local Government Areas (LGAs) selected from Rivers State and Enugu State. The LGAs were randomly selected, one from each of the three senatorial zones in each state; Etche and Ogu/Bolo (Rivers East), Ogba/Egbema/Ndoni (Rivers West), Eleme (Rivers South-East) LGA in Rivers State, as well as from Enugu-East (Enugu East), Nsukka (Enugu North), and Aninri (Enugu West) LGA in Enugu State. A total of 26 vegetables were harvested and studied; 12 vegetables of 4 kinds from Enugu State and 14 vegetables of 4 kinds from Rivers State. About $150 \mathrm{~g}$ of each vegetable was collected from each LGA. 
The harvested vegetables were transported in a self-sealed black nylon bag to where their leaves were plucked from the stem and the bruised or rotten parts removed to avoid contamination. They were washed-off of external dirt with deionized water and were placed in a colander under open air to allow drain off of excess water [17] and air dried. Each leaf kinds were later packaged in a brown paper bag and stored at $8-10^{\circ} \mathrm{C}$ in a refrigerator till ready for analysis.

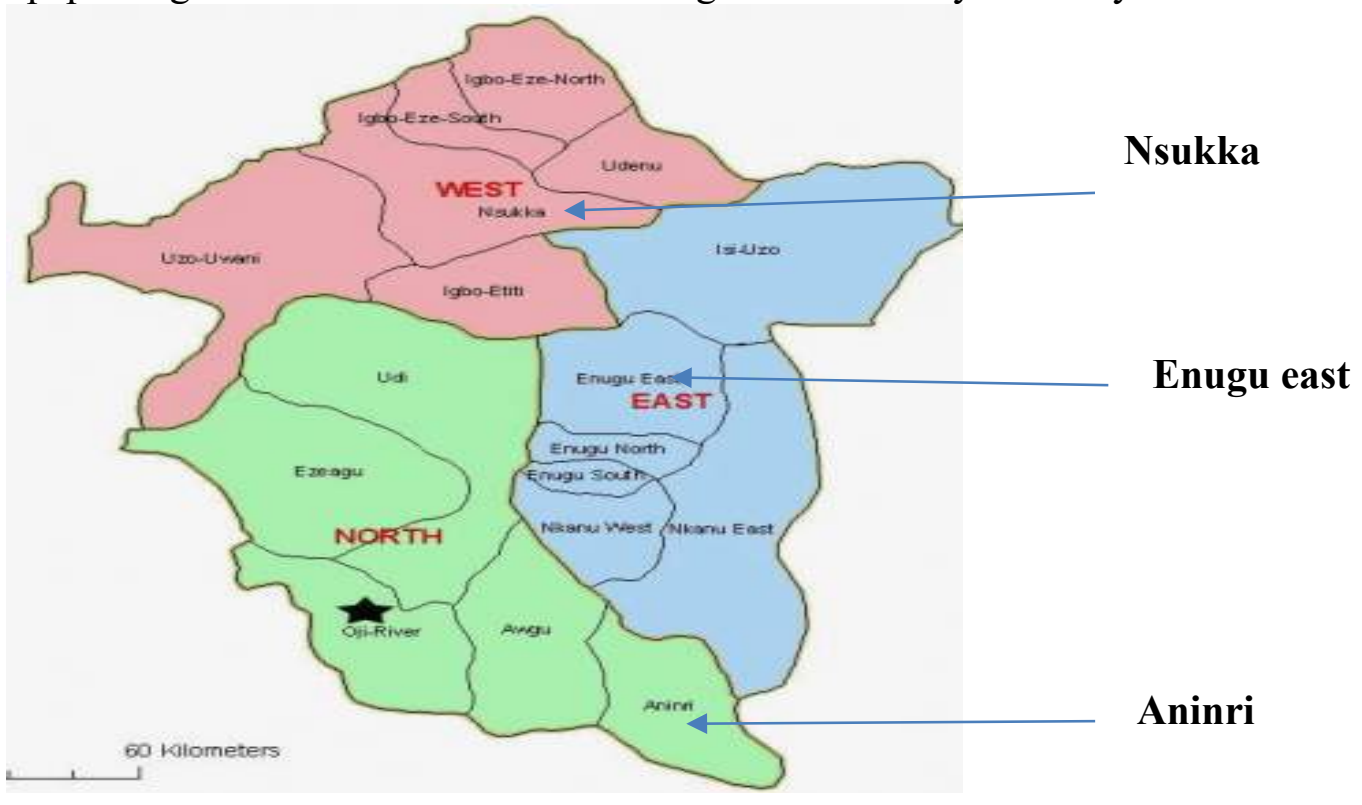

Figure 1: Enugu state with arrow showing sampling sites.

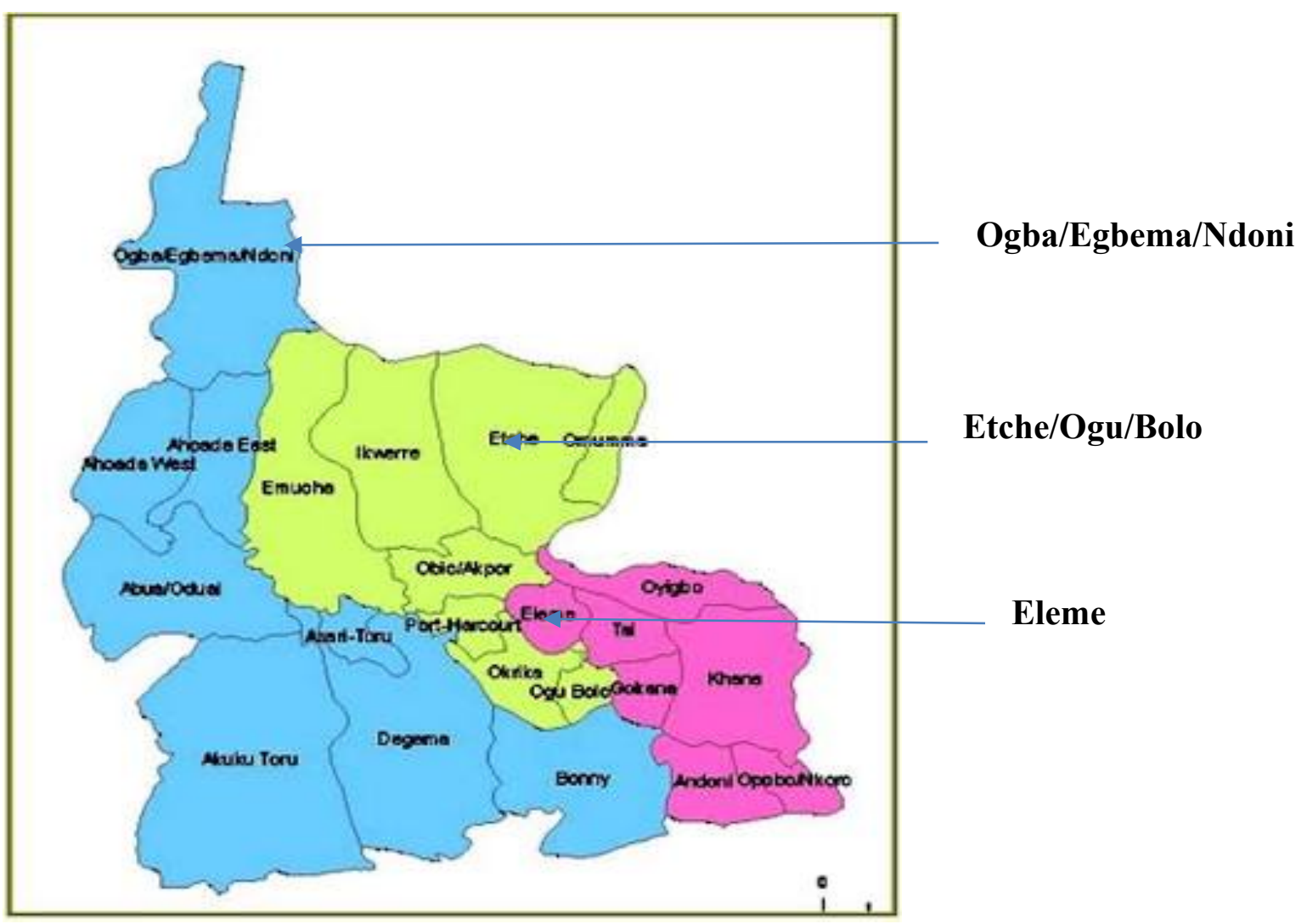

Figure 2: Rivers State with arrows showing sampling sites.

\section{Analytical Procedures}

Chemical analysis (of some Heavy metals) of the vegetables was determined using various standard methods [12]. Proper quality assurance was ensured with the help of the lab technician to 
ensure the reliability of the results. Deionized water was used throughout the study. Reagent blank determinations were used for corrections to the instrument readings.

\section{Heavy metal determination}

The methods of $[18,13,19]$ were used to determine the lead, cadmium and mercury using Flameless Atomic Absorption Spectrophotomer (AAS, Perkin Elmer Model 2130).

\section{Sample preparation}

A $1-2 \mathrm{~g}$ test portion of homogenized material was weighed to the nearest $0.01 \mathrm{~g}$, and transferred to a $250 \mathrm{ml}$ beaker. The solution was evaporated to $5 \mathrm{ml}$ and allowed to cool. A $2 \mathrm{ml}$ water and $3 \mathrm{ml} \mathrm{30 \%} \mathrm{H}_{2} \mathrm{O}_{2}$ was added and covered with watch glass, then heated slowly (to avoid losses by excessive reaction) to initiate peroxide reaction. Heating continued until effervescence subsided and the solution was allowed to cool. A $7 \mathrm{ml} \mathrm{30 \%} \mathrm{H}_{2} \mathrm{O}_{2}$ was then added, $1 \mathrm{ml}$ at a time, while warming (so that all samples will receive $30 \% \mathrm{H}_{2} \mathrm{O}_{2}$ and reagent blank contribution from $\mathrm{H}_{2} \mathrm{O}_{2}$ was constant). Solution was allowed to cool, then $5 \mathrm{ml}$ conc. $\mathrm{HCl}$, and $10 \mathrm{ml}$ water was added, covered with watch glass and solution was left to reflux for another 15 minutes without boiling. Solution was allowed to cool, diluted to $100 \mathrm{ml}$ water, and mixed. Particulate matter in digest were removed by filtration, centrifugation or settling.

\section{Determination of heavy metals}

Lead, Cadmium and Mercury were determined using the Flameless Atomic Absorption Spectrophotometric (AAS, Perkin Elmer model 2130) method. Twenty five $(25 \mathrm{ml})$ of sample was transferred from digestion solution of each sample to another digestion flask. Volume was adjusted to about $100 \mathrm{ml}$ with diluting solution. Output of pump was adjusted to approximately $21 \mathrm{air} / \mathrm{min}$ by regulating speed of pump with variable transformer. Apparatus was connected except for gas inlet adapter with pump working and spectrophotometer zeroed; $20 \mathrm{ml}$ of reducing solution was added to diluted aliquot. Immediately gas inlet adapter was connected and aerated for about 3 minutes. Adsorbance (A) was recorded, then pressure on 'out' side of pump was disconnected, and vent of filter flask was opened to flush system [20].

Calculation: Calculation involves subtraction of reagent blank values and adjustment for wet weight of test portions (multiply by wet weight fraction), digest volume and any additional dilutions.

$$
\mathrm{Cs}=(\mathrm{Ic}-\mathrm{B}) \times \mathrm{D} \times \mathrm{R},
$$

where $\mathrm{B}=$ reagent blank concentration, $\mathrm{mg} / \mathrm{L} ; \mathrm{Cs}=$ concentration of element in test portion, $\mathrm{mg} / \mathrm{kg}$; $\mathrm{D}=$ dilution factor $(=50$ when preparation of $2 \mathrm{~g}$ test portion results in $100 \mathrm{~mL}$ solution and no extra dilution is required); Ic = test solution digest concentration from instrument, $\mathrm{mg} / \mathrm{L} ; \mathrm{R}=$ wet weight/dry weight ratio for test portion.

\section{Statistical Analysis}

Data was analyzed using SPSS version 21. Significance of heavy metals detected in vegetables from two different locations were determined using student T-test while the significance of heavy metals detected in vegetables from more than two locations were determined using ANOVA after which the means were separated using Duncan's new multiple range test (DNMRT). One sample T-test was used to compare the FAO/WHO recommended values to the values obtained from the field study. These tests were carried out at $5 \%$ probability $(\mathrm{p}<0.05)$.

\section{Results}

Figs. 3, 4, and 5 shows the heavy metal (HM) content of Murraya koenigii harvested from Local Government Areas (LGA) in Enugu State and Rivers State (mg/100g). The result showed significant differences $(p<0.05)$ for the HM content of vegetables harvested from both States. The 
Cd value of 0.19 in Enugu-East LGA was lowest compared to the value of 0.25 observed in Nsukka LGA which was the highest, while a $\mathrm{Cd}$ value of 0.22 was the case in Aninri LGA. However, $\mathrm{Pb}$ levels were reported to have the highest value of 0.26 in Enugu-East LGA and least value of 0.22 in Nsukka LGA, while a $\mathrm{Pb}$ value of 0.24 was the case in Aninri LGA was. The result showed the same $\mathrm{Hg}$ contents of 0.01 for the three LGA studied in Enugu State. Also, reports gathered for Rivers State indicated significant differences $(\mathrm{p}<0.05)$ only for $\mathrm{Pb}$ and $\mathrm{Hg}$ contents in the LGA. The $\mathrm{Pb}(0.29)$ and $\mathrm{Hg}(0.02)$ values were highest in Eleme LGA than the values observed in Etche LGA for $\mathrm{Pb}(0.25)$ and $\mathrm{Hg}$ (0.02). Although, higher Cd value was observed in Etche LGA (0.15) than was the case for Eleme LGA $(0.14)$, the Cd value did not differ significantly $(p<0.05)$ for both LGA.

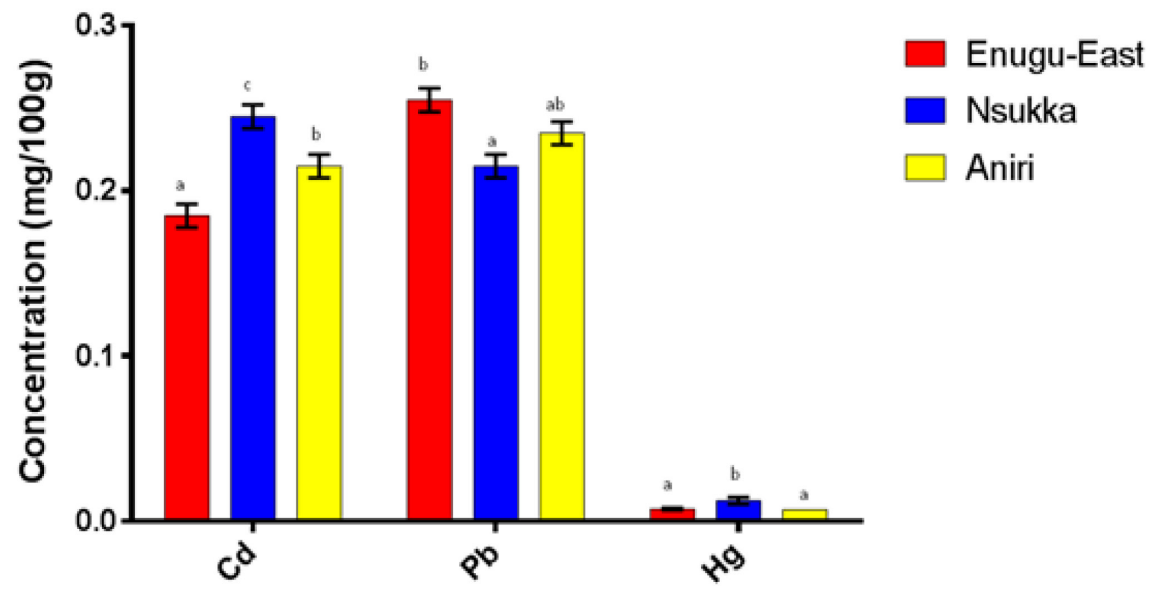

Figure 3: Heavy metal content of Murraya koenigii leaves harvested from LGA in Enugu State (mg/100g).

Key:

$\mathbf{C d}=$ Cadmium

$\mathbf{P b}=$ Lead

$\mathbf{H g}=$ Mercury

Error bars represent mean \pm standard deviation

Bars with different superscripts are statistically different at $\mathrm{p}<0.05$ probability level.

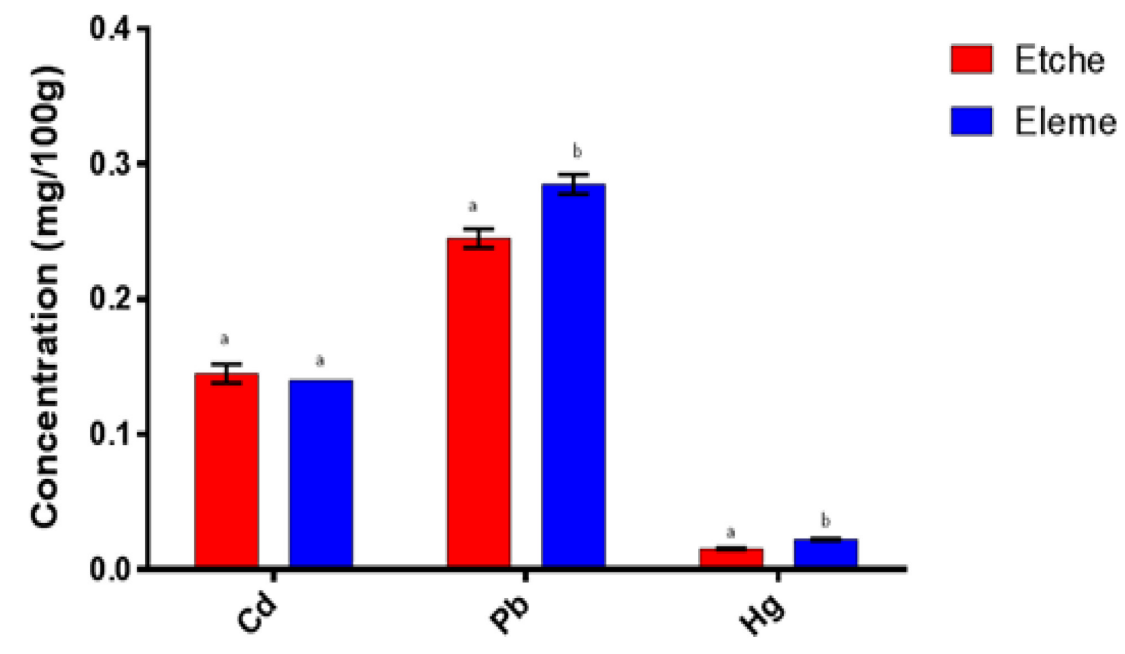

Figure 4: Heavy Metal content of Murraya koenigii leaves harvested from LGA in Rivers State $(\mathrm{mg} / 100 \mathrm{~g})$.

Key:

$\mathbf{C d}=$ Cadmium

$\mathbf{P b}=$ Lead

$\mathbf{H g}=$ Mercury

Error bars represent mean \pm standard deviation

Bars with different superscripts are statistically different at $\mathrm{p}<0.05$ probability level. 


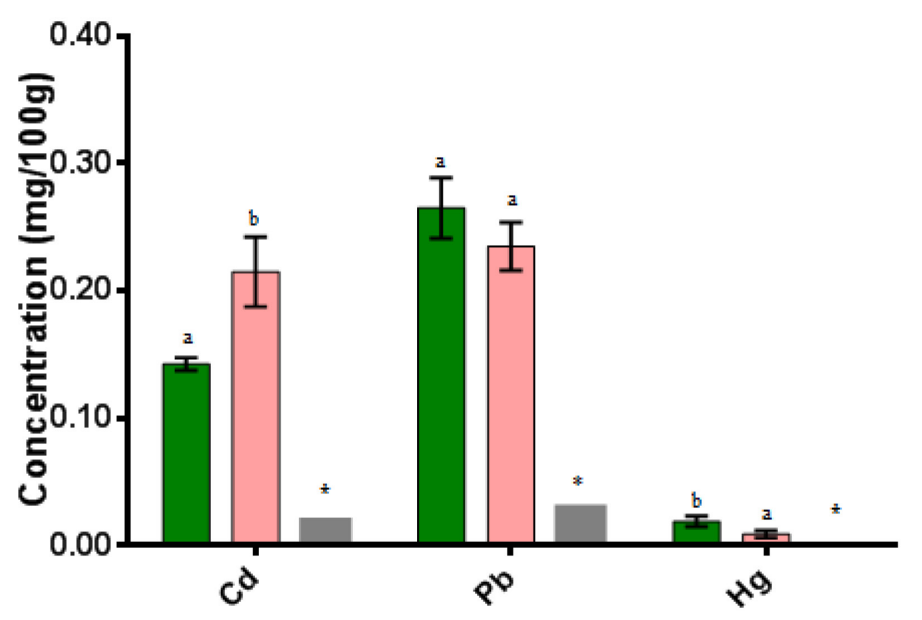

$\square$ Rivers

$\square$ Enugu

FAO/WHO

Figure 5: Mean HM content of Murraya koenigii leaves in Enugu State compared to Rivers State $(\mathrm{mg} / 100 \mathrm{~g})$.

Key:

Cd $=$ Cadmium

$\mathbf{P b}=$ Lead

$\mathbf{H g}=$ Mercury

* FAO/WHO reference critical level of heavy metals

Error bars represent mean \pm standard deviation

Bars with different superscripts are statistically different at $\mathrm{p}<0.05$ probability level.

Figs. 6, 7 and 8, shows the HM content of Ocimium gratissimum leaves harvested from Local Government Areas (LGA) in Enugu and Rivers States (mg/100g). No significant difference was recorded among all the LGA studies in Enugu State for $\mathrm{Cd}, \mathrm{Pb}$ and $\mathrm{Hg}$ contents of Ocimium gratissimum. The Cd values were 0.09 in Enugu-East LGA, 0.07 in Nsukka LGA and 0.09 in Aninri LGA. Also, the Pb levels were 0.20 in Enugu-East LGA, 0.19 in Nsukka LGA, and 0.18 in Aninri LGA, while $\mathrm{Hg}$ had the same values of 0.02 for Enugu-East, Nsukka, and Aninri LGA. Alternatively, significant differences $(p<0.05)$ were recorded for the LGA in Rivers State. Although, Ogba/Egbema/Ndoni LGA and Ogu/Bollo LGA were significantly $(\mathrm{p}>0.05)$ higher compared to Etche LGA and Eleme LGA, both Ogba/Egbema/Ndoni and Ogu/Bollo had the same Cd value of 0.13 as well as Etche LGA and Eleme LGA which both had the same Cd values of 0.09. Lead also had significantly highest value for Ogu/Bollo (0.33) compared to Etche (0.24), Ogba/Egbema/Ndomi (0.26), and Eleme (0.27). The Hg contents for Ogba/Egbema/Ndomi LGA, Eleme LGA and Ogu/Bollo LGA $(0.02,0.02$, and 0.02 respectively) were comparably ( $\mathrm{p}>0.05)$ same and differed significantly $(\mathrm{p}<0.05)$ from the $\mathrm{Hg}$ content of Etche LGA (0.02). 


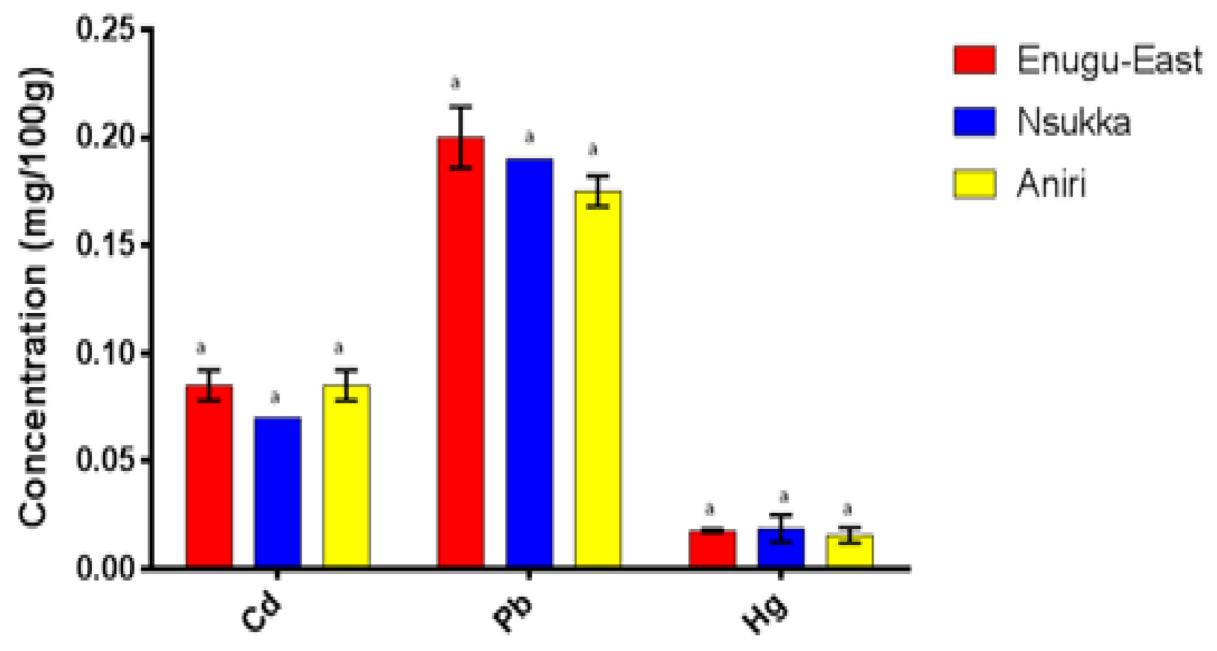

Figure 6: Heavy Metal content of Ocimium gratissimum leaves harvested from LGA in Enugu State $(\mathrm{mg} / 100 \mathrm{~g})$.

Key:

$\mathbf{C d}=$ Cadmium

$\mathbf{P b}=$ Lead

$\mathbf{H g}=$ Mercury

Error bars represent mean \pm standard deviation.

Bars with different superscripts are statistically different at $\mathrm{p}<0.05$ probability level.

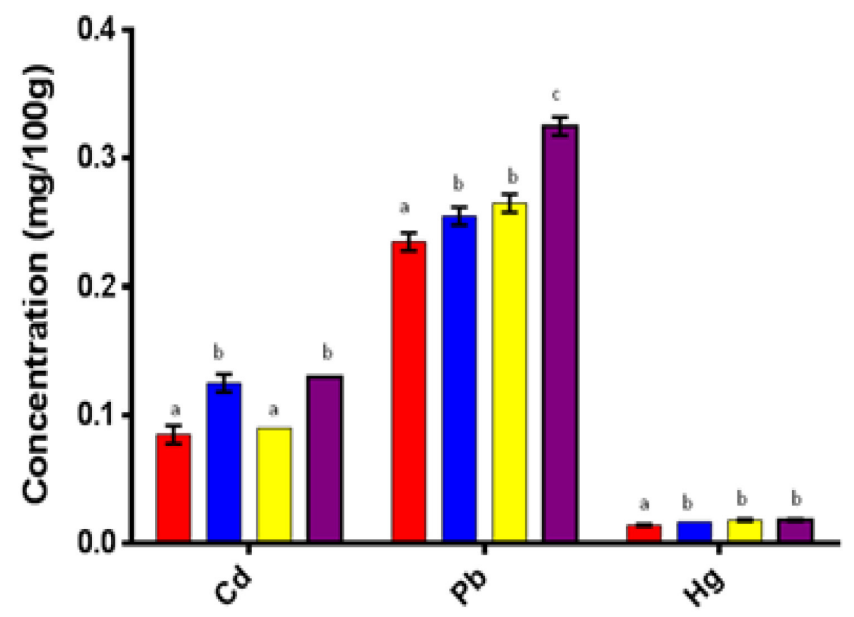

Figure 7: Heavy Metal content of Ocimium gratissimum leaves harvested from LGA in Rivers State $(\mathrm{mg} / 100 \mathrm{~g})$.

Key:

$\mathrm{Cd}=$ Cadmium

$\mathrm{Pb}=$ Lead

$\mathrm{Hg}=$ Mercury

Error bars represent mean \pm standard deviation.

Bars with different superscripts are statistically different at $\mathrm{p}<0.05$ probability level. 


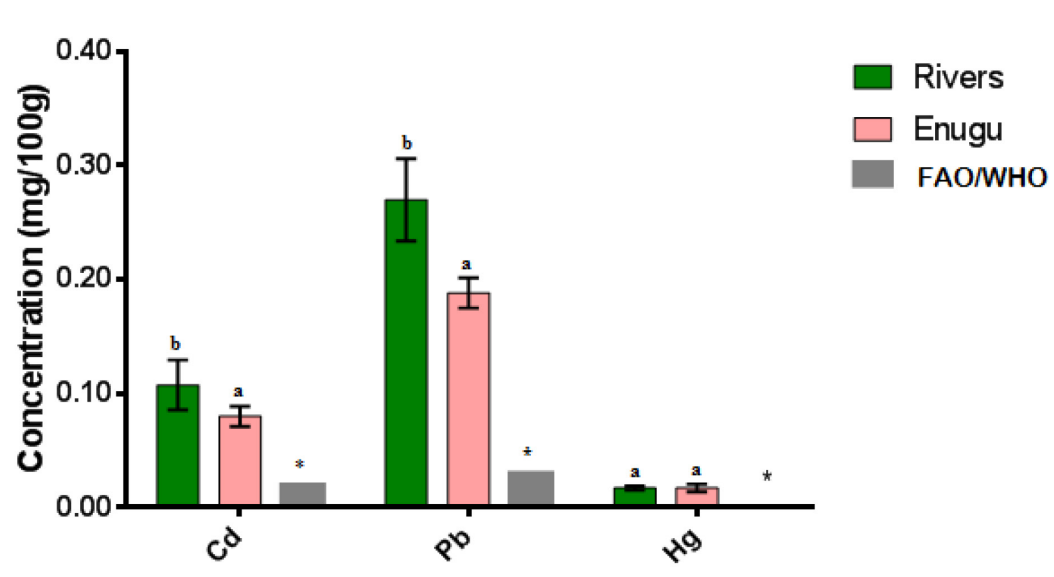

Figure 8: Mean Heavy Metal content of Ocimium gratissimum leaves in Enugu State compared to Rivers State (mg/100g).

Key:

$\mathbf{C d}=$ Cadmium

$\mathbf{P b}=$ Lead

$\mathbf{H g}=$ Mercury

* FAO/WHO reference critical level of heavy metals

Error bars represent mean \pm standard deviation

Bars with different superscripts are statistically different at $\mathrm{p}<0.05$ probability level.

Figs. 9, 10, and 11, shows the HM content of Telfaria occidentialis leaves harvested from Local Government Areas (LGA) in Enugu and Rivers States (mg/100g). Significant differences were observed among the LGA in Enugu State for the HM contents. Cadmium content was significantly least $(\mathrm{p}<0.05)$ in Nsukka LGA $(0.13)$ compared to the outcome in Enugu-East and Aninri, 0.16 and 0.17 respectively. Also, the Lead level was significantly highest $(\mathrm{p}<0.05)$ in Aninri LGA (0.27) compared to Nsukka LGA which had the least outcome of 0.23, while $\mathrm{Hg}$ had results that was significantly $(\mathrm{p}<0.05)$ higher in Enugu-East $(0.01)$ than in Nsukka LGA $(0.01)$ and Aninri LGA (0.00). Similarly, significant differences were recorded between the LGA in Rivers State, whereby Cd content was significantly comparable $(p>0.05)$ for Etche, Eleme, and Ogu/Bollo LGA whish had similar values of 0.12 . On the other hand, Ogba/Egbema/Ndomi LGA was significantly $(\mathrm{p}<0.05)$ lower with a Cd value of 0.08 . The Lead values differed significantly $(\mathrm{p}<$ 0.05) in the LGA with outcomes as 0.19 in Etche, 0.29 in Ogba /Egbema/Ndomi which was significantly $(\mathrm{p}<0.05)$ highest, 0.24 in Eleme and 0.23 in $\mathrm{Ogu} /$ Bollo, while the $\mathrm{Hg}$ content was significantly highest for Ogba /Egbema/Ndomi (0.02)and least for Etche (0.01).

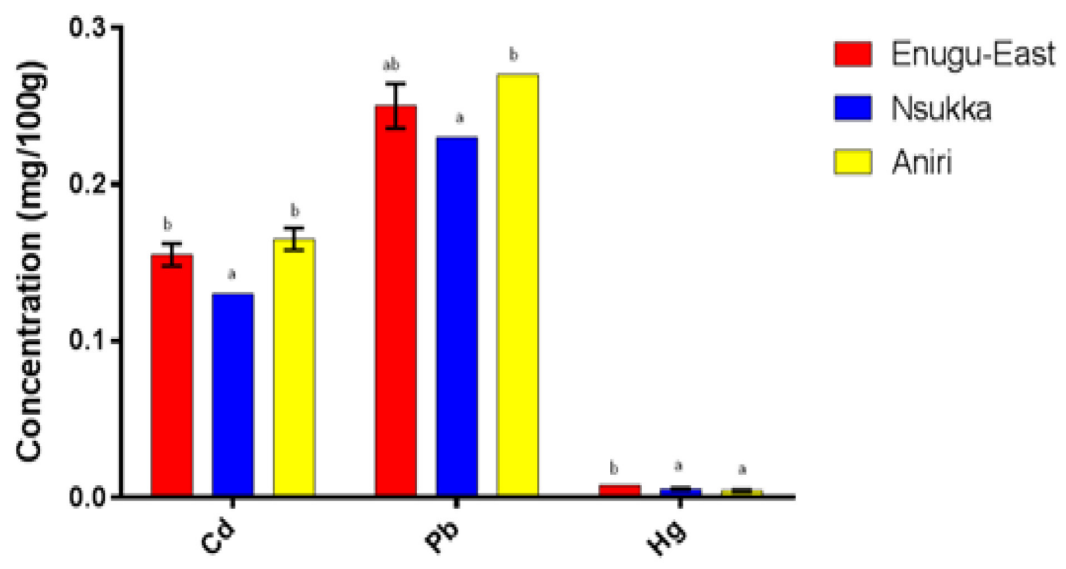

Figure 9: Heavy Metal content of Telfaria occidentialis leaves harvested from LGA in Enugu State $(\mathrm{mg} / 100 \mathrm{~g})$.

Key:

$\mathbf{C d}=$ Cadmium

$\mathbf{P b}=$ Lead

$\mathbf{H g}=$ Mercury

Error bars represent mean \pm standard deviation

Bars with different superscripts are statistically different at $\mathrm{p}<0.05$ probability level. 


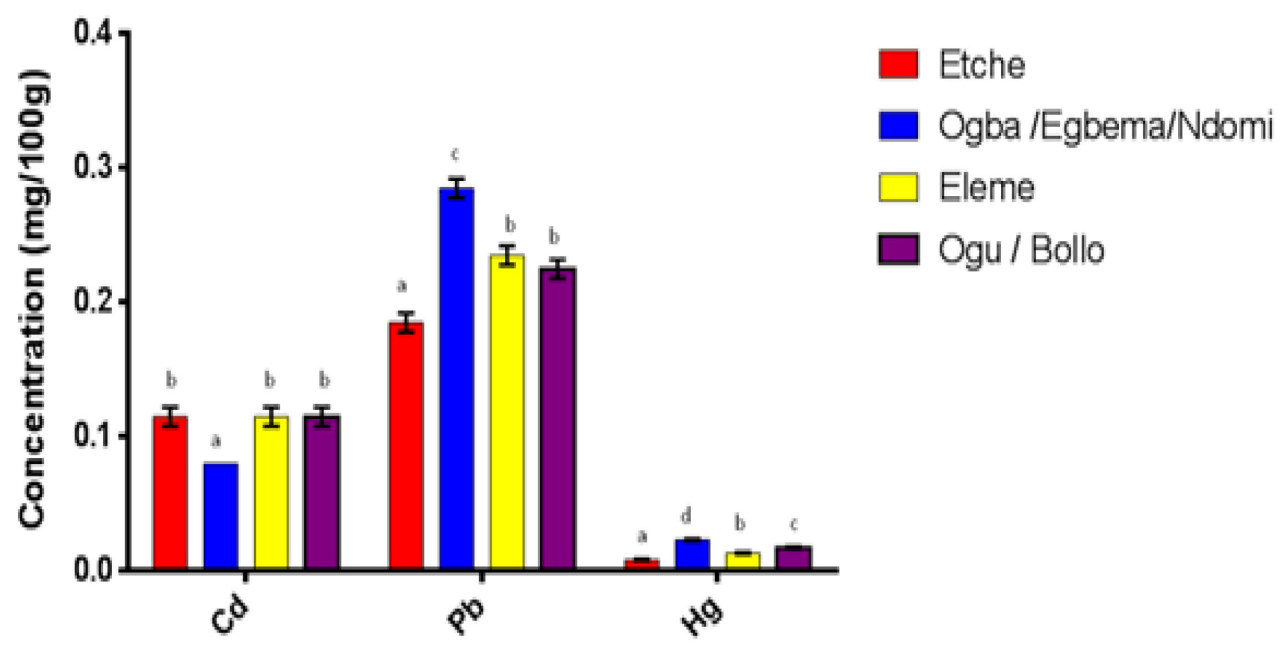

Figure 10: Heavy Metal content of Telfaria occidentialis leaves harvested from LGA in Rivers State $(\mathrm{mg} / 100 \mathrm{~g})$.

Key:

$\mathbf{C d}=$ Cadmium

$\mathbf{P b}=$ Lead

$\mathbf{H g}=$ Mercury

Error bars represent mean \pm standard deviation

Bars with different superscripts are statistically different at $\mathrm{p}<0.05$ probability level.

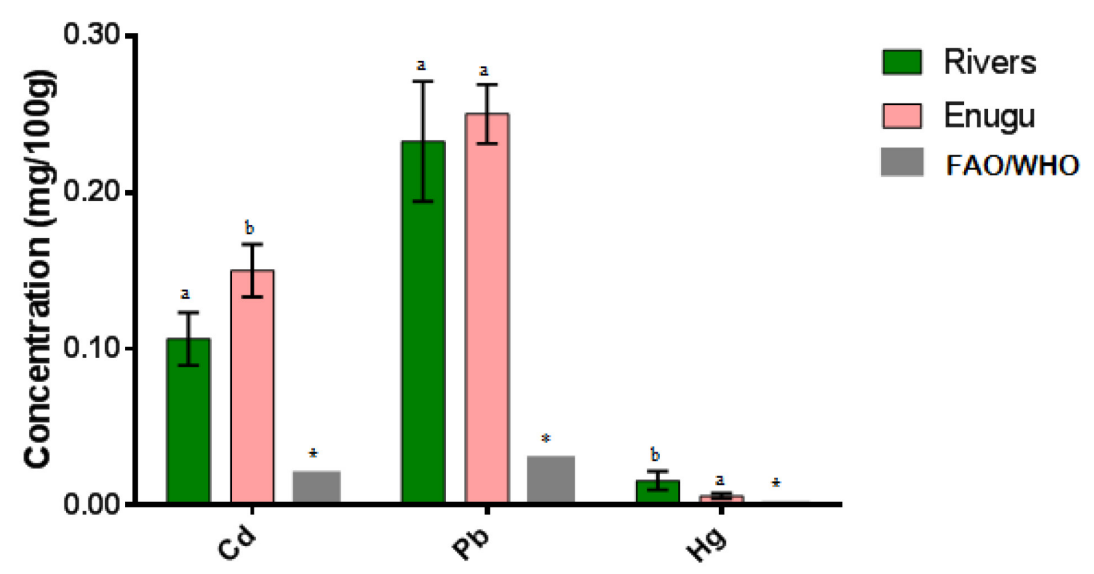

Figure 11: Mean Heavy Metal content of Telfaria occidentialis leaves in Enugu State compared to Rivers State.

Key:

$\mathbf{C d}=$ Cadmium

$\mathbf{P b}=$ Lead

$\mathbf{H g}=$ Mercury

* FAO/WHO reference critical level of heavy metals

Error bars represent mean \pm standard deviation

Bars with different superscripts are statistically different at $\mathrm{p}<0.05$ probability level.

Figs. 12, 13, and 14, shows the HM content of Talinum triangulare leaves harvested from Local Government Areas (LGA) in Enugu and Rivers States (mg/100g). Significant differences ( $\mathrm{p}<$ 0.05) were recorded only for $\mathrm{Cd}$ and $\mathrm{Hg}$ in the LGA in Enugu State. Cadmium was significantly highest $(\mathrm{p}<0.05)$ in Aninri LGA with the value of 0.25 when compared to the outcomes in Nsukka $(0.19)$ and Enugu-East (0.16). The Pb levels were without any significant differences $(\mathrm{p}<0.05)$ between Enugu-East LGA (0.20), Nsukka LGA (0.23), and Aninri LGA. Also, Rivers State had significant differences across all the LGA with Cd levels significantly highest $(p<0.05)$ in Ogba /Egbema/Ndomi LGA with a value of 0.16 and lowest $(p<0.05)$ in Eleme LGA with a value of 0.07. Etche LGA had a $\mathrm{Cd}$ value of 0.08 and $\mathrm{Ogu} /$ Bollo had a value of 0.09 . Lead differed significantly $(\mathrm{p}<0.05)$ in the LGA with Eleme being highest with the value 0.34 , while 
$\mathrm{Ogba} /$ Egbema/Ndoni LGA was the least with the value 0.19. Etche LGA with the value 0.27 did not differ significantly from Ogu/Bollo which had the value of 0.26. Similarly, Mercury content differed significantly $(p<0.05)$ whereby Etche $(0.03)$ and Eleme $(0.03)$ LGA were comparably higher, while Ogba/Egbema/Ndomi (0.01) and Ogu/Bollo (0.01) where comparably lower.

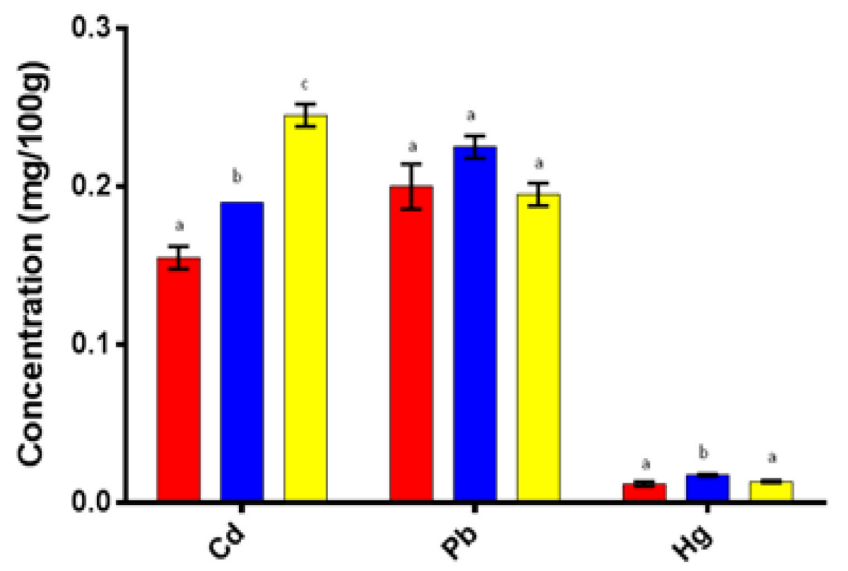

Figure 12: Heavy Metal content of Talinum triangulare leaves harvested from LGA in Enugu States $(\mathrm{mg} / 100 \mathrm{~g})$.

Key:

$\mathbf{C d}=$ Cadmium

$\mathbf{P b}=$ Lead

$\mathbf{H g}=$ Mercury

Error bars represent mean \pm standard deviation

Bars with different superscripts are statistically different at $\mathrm{p}<0.05$ probability level.
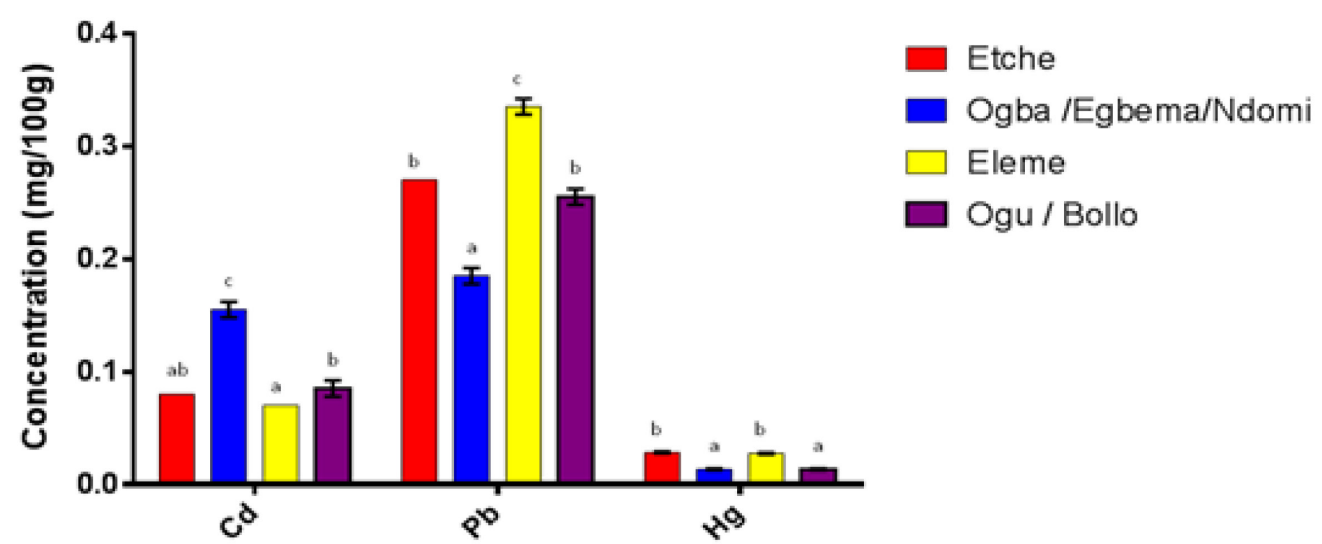

Figure 13: Heavy Metal content of Talinum triangulare leaves harvested from LGA in Rivers States $(\mathrm{mg} / 100 \mathrm{~g})$.

Key:

Cd $=$ Cadmium

$\mathbf{P b}=$ Lead

$\mathbf{H g}=$ Mercury

Error bars represent mean \pm standard deviation

Bars with different superscripts are statistically different at $\mathrm{p}<0.05$ probability level. 


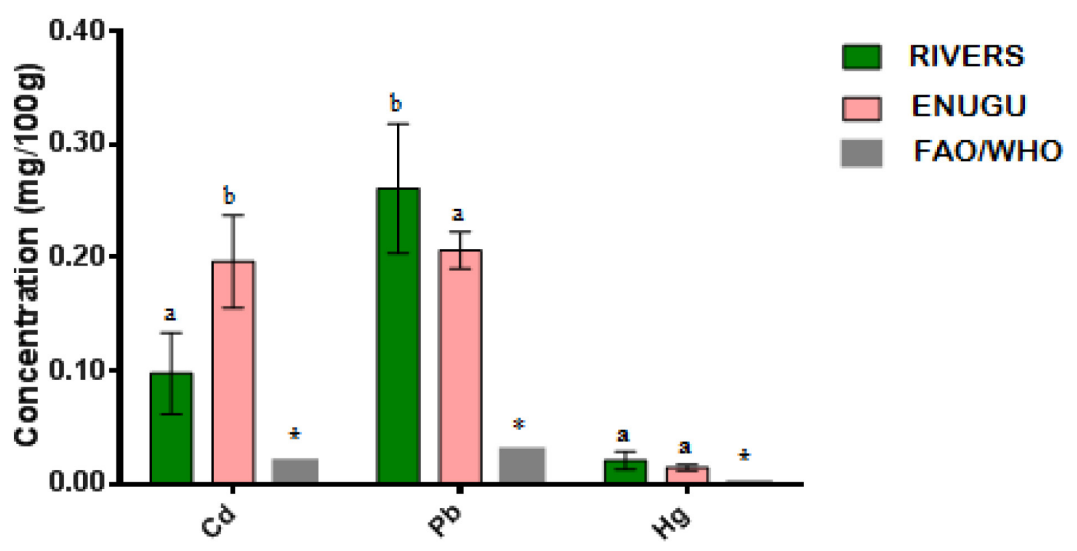

Figure 14. Mean Heavy Metal content of Talinum triangulare leaves in Enugu State compared to Rivers State (mg/100g).

Key:

$\mathbf{C d}=$ Cadmium

$\mathbf{P b}=$ Lead

$\mathbf{H g}=$ Mercury

*FAO/WHO reference critical level of heavy metals

Error bars represent mean \pm standard deviation

Bars with different superscripts are statistically different at $\mathrm{p}<0.05$ probability level.

\section{Discussion and Conclusion}

Many toxic HMs act as molecular "mimics" of nutritionally essential trace elements; as a result, they may compete with essential metallic cofactors for entry into cells and incorporation into enzymes [21]. The HM ions form complexes with proteins binding with the carboxylic acid, amine and thiol groups in the molecule. These modified biological molecules lose their ability to function properly and result in the malfunction or death of the cells. When metals bind to these groups, they inactivate important enzyme systems, or affect protein structure, which is linked to the catalytic properties of enzymes. This type of toxin may also cause the formation of radicals, dangerous chemicals that cause the oxidation of biological molecules [22]. It was seen in Figs. 5, 8, 11 and 14 that all the HMs $(\mathrm{Pb}, \mathrm{Cd}, \mathrm{Hg})$ were above the maximum permissible level set by $\mathrm{FAO} / \mathrm{WHO}$ [23] in the various LGAs studied. HM concentrations were also higher than the safe limits given by [24]. The main sources of these toxic metals were the heavy traffic emission as was observed in both cities due to urbanization and industrialization. These environmental conditions were agree with the findings and report of [25] who pointed out detrimental conditions of Enugu and Rivers State implicated by environmental degradation such as improper disposal of refuse near residential areas and poor refuse collection and handling. The results obtained revealed that the mean level of cadmium $(\mathrm{Cd})$ was very significant $(\mathrm{p}<0.05)$ for all the locations studied. Cadmium $(\mathrm{Cd})$ had the highest concentration in Enugu State than Rivers State for all the vegetables, except for Ocimium gratissimum which was significantly $(\mathrm{p}<0.05)$ lower in Rivers State than in Enugu State (Fig. 3, 9 and 12). The $\mathrm{Cd}$ values were higher than what was obtained in the findings of [25] which had values of $0.02 \mathrm{mg} / \mathrm{kg}, 0.01 \mathrm{mg} / \mathrm{kg}$ and $0.01 \mathrm{mg} / \mathrm{kg}$ for Amaranthus hybridus, Cochorus olitorus (ewedu in Yoruba) and Celosia argentea (soko) plants respectively. Cadmium can be emitted from tyre, detergent, and battery products, as well as, domestic wastes and poor sewage disposal which were the environmental condition in most parts of Enugu State. [26], in their study, explained that soils at refuse dumpsites contain different kinds and concentrations of HM depending on the age, contents and location of the dumpsite. Similarly, many studies have shown that continuous disposal of municipal wastes may increase the HM concentration in the soil and underground water [27-30]. Welders and other mechanics associated with the automobile industry also release a lot of Cd in the environment.

Furthermore, industrial activities such as mining, petroleum and chemical manufacturing emit $\mathrm{Cd}$ into the environment. Cadmium is non-essential to living organisms and can become toxic by 
displacing zinc. Even at acute concentrations, Cd may result in kidney damage [31]. Also, epidemiological studies have revealed that cadmium may be a contributing factor in some forms of cancer such as urothelial, gastric, colorectal cancer in humans [32]. Lead is a serious cumulative body poison and cannot be removed by washing fruits and vegetables [33]. Although the mean levels of lead in Enugu compared to Rivers State showed significant differences $(\mathrm{p}<0.05)$ for only Ocimium gratissimum and Talinum triangulare, Rivers State had the highest mean values for $\mathrm{Pb}$ concentrations in all the vegetables except for Telfaria occidentialis (Fig. 9) which was not significantly ( $\mathrm{p}>0.05)$ highest in Enugu State compared to Rivers State. The observed $\mathrm{Pb}$ content for the vegetables in all the locations ranged from $0.18 \mathrm{mg} / 100 \mathrm{~g}$ to $0.34 \mathrm{mg} / 100 \mathrm{~g}$ and was higher compared to the findings of [26] which ranged from $0.001 \mathrm{mg} / \mathrm{kg}$ to $0.123 \mathrm{mg} / \mathrm{kg}$ for Amaranthus hybridus, Cochorus olitorus and Celosia argentea plants. [34] observed highest values of 28.38$67.78 \mathrm{mg} / \mathrm{kg}$ for lead contents in soils from Port Harcourt. Leaded gasoline in Nigeria contains lead in the concentration range of 0.65 to $0.74 \mathrm{~g} / \mathrm{L}$ and this was rated highest among some countries; USA $(0.00 \mathrm{~g} / \mathrm{L}), \mathrm{UK}(0.00 \mathrm{~g} / \mathrm{L})$, and South Africa $(0.33 \mathrm{~g} / \mathrm{L})[35,36]$. Oil pollution as was evident in most parts of Rivers State and has been documented to limit the micronutrient composition of crops cultivated in oil-polluted farms [37]. Lead exposure is most evident in environments characterized by mining, petroleum combustion, exhaust fumes from cars and industrial effluents. These environmental conditions are inevitable but, if improperly treated or channeled, residual toxicants which can bioaccumulate in the food chain can be emitted, even after many years of incidence because they are not biodegradable.

Mercury is a naturally occurring metallic element which can be present in foodstuffs by natural causes; elevated levels can also occur due to e.g., environmental contamination by industrial or other uses of mercury [38]. The research findings indicated significant differences $(p<0.05)$ in the mercury $(\mathrm{Hg})$ outcomes only for Murraya koenigii and Telfaria occidentialis in Rivers State. Rivers State still reported averagely highest $(0.01$ to $0.03 \mathrm{mg} / 100 \mathrm{~g})$ for $\mathrm{Hg}$ concentrations than in Enugu State $(0.00$ to $0.02 \mathrm{mg} / 100 \mathrm{~g})$ (Firs. 5, 8, 11 and 14). [39] has indicated that the total mercury levels in plants are usually very low and the low mean levels of $\mathrm{Hg}$ in this study suggests that activities in the production of $\mathrm{Hg}$ are very low in the study locations. Also, the Food and Drug administration (Codex Alimentarius Commissiom (CAC), [40] has indicated that $\mathrm{Hg}$ is widely distributed at low levels in the environment. Mercury had the least outcomes compared to the rate of occurrence of lead and cadmium in the study. The 72nd Joint FAO/WHO Expert Committee on Food Additives [41, 42] noted that there has been a lack of quantitative data on methylmercury in non-fish products and on inorganic mercury in foods in general. Mercury is not considered in most research works which has made it impossible to compare the findings of this study to other works. Heavy metals can bind to vital cellular components, such as structural proteins, enzymes, and nucleic acids, and interfere with their functioning [43].

Generally, the inference of this research depicts that lead and mercury concentrations were relatively higher in vegetable obtained from crude oil producing state (River state) than those obtained from non-crude oil producing state (Enugu), while the reverse was the case for cadmium. Owing to these observed toxicants in these localities, it is pertinent to advice the local communities against consuming these vegetables. Even though this will limit their nutrient intake and reduce their source of income; hence the need for home gardens away from sewage, refuse, domestic and industrial. Also, there is need for awareness campaign on the need for consuming antioxidant-rich food sources to facilitate HM detoxification/excretion from their body system. Vegetables on the other hand have been reported to accumulate more HM in their leafy system compared to grain or fruit vegetables [44] therefore, the need to incorporate other classes of antioxidant rich vegetables and grains e.g. nuts, seeds, ginger, soybeans, tomatoes, berries, onions, garlics, grapes, and other food sources [45] are of special importance as natural antagonists to HM toxicity and should be consumed on a regular basis.

\section{Conflict of Interest}

The authors declare that there is no conflict of interest. 


\section{References}

[1] S. Zhen-Guo et al., Lead Phytoextraction from contaminated soil with highbiomass plant species, Journal of Environmental Quality. 31 (2002) 1893-1900.

[2] A.K. Bhattacharya, S.N. Mandal, S.K. Das, Heavy metals accumulation in water, sediment and tissues of different edible fishes in upper stretch of gangetic West Bengal, Trends in Applied Science Research. 3 (2008) 61-68.

[3] L.I.N. Ezemonye, M.O. Kadiri, Biorestoration of the Aquatic Ecosystem: The African perspective, Environmental Review. 3(1) (2000) 137-147.

[4] USEPA. Risk Assessment Guidance for Superfund (RAGS) Development of Risk-Based Preliminary Remediation Goals, Volume I, Human Health Evaluation Manual, (Part B). EPA/540/R-92/003. Washington, D.C.: United States Environmental Protection Agency, 1991, 112.

[5] A. Adefris, Heavy Metal toxicity Clinical, Department of Emergency Medicine, Kings County Hospital Center, State University of New York Downstate Medical Center, 2015, pp. 23-31.

[6] A. Galanis, A. Karapetsas, R. Sandaltzopoulos, Metal-induced carcinogenesis, oxidative stress and hypoxia signaling, Mutat. Res. 674(1-2) (2009) 31-35.

[7] P. Koedrith, Y.R. Seo, Advances in carcinogenic metal toxicity and potential molecular markers. Int. J. Mol. Sci. 12(12) (2011) 9576-9595.

[8] S. Malkoç, Street dust pollution of some metals along Eskisehir urban roads, Turkey, 2011.

[9] S. Khan et al., Health risk of heavy metals in contaminated soils and food crops irrigated with waste water in Beijing, China, Environmental Pollution. 152 (3) (2008) 686-692.

[10] F. M. Marshall et al., Contaminated Irrigation Water and Food Safety for the Urban and Periurban Poor. Appropriate Measures for Monitoring and Control from Field Research in India and Zambia, University of Sussex, 2007.

[11] C.M.A. Ademoroti, Levels of trace heavy metals on bark and fruit of trees in Benin city, Nigeria, International Journal of Environmental Pollution. 4 (1996) 241-253.

[12] A.A. Amusan, P.V. Ige, R. Oluwale. Preliminary investigation on the use of municipal waste dump for farming, in: The 25th Annual Conference of Soil Science Society of Nigeria, Nov. 21-25, Benin City, Nigeria, 1999, pp. 1-34.

[13] O. Otitoju et al., Heavy metal contamination of Green leaf vegetable Gardens in Itam Road Construction site in Uyo, Nigeria, Research Journal of Environmental Earth Science. 4(4) (2012) $371-375$.

[14] L. Jarup, Hazards of heavy metal contamination. Department of Epidemiology and Public Health, Imperial College, London, UK. British Medical Bulletin. 68 (2003) 167-182.

[15] M. Liu et al., Distribution and ecological assessment of heavy metals in surface sediments of the East Lake, China, Ecotoxicology. 23(1) (2014) 92-101.

[16] A. Galadima, Z.N. Garba, Recent Issues in Environmental Science. "Including incidences and reports from Nigeria”. Lap Lambert Academic Publishers, Germany, 2012.

[17] M.A. Elbagermi, H.G.M. Edwards, A.I. Alajtal, Monitoring of Heavy Metal Content in Fruits and Vegetables Collected from Production and Market Sites in the Misurata Area of Libya, ISRN Analytical Chemistry. 2012 (2012) ID 827645.

[18] O.E. Orisakwe, et al., Heavy metals health risk assessment for population via consumption of food crops and fruits in Owerri, South Eastern, Nig. Chem. Cen. J. 6(1) (2012) 77-82. 
[19] I.A. Kalagbor, K. Opusunju, A comparison study of dry and wet ashing methods used for the assessment of concentration of five heavy metals in three vegetables from Rivers State, Nigeria, Int. Res. J. Public Environ. Health. 2(2) (2015) 16-22.

[20] AOAC, Association of Official Analytical Chemists Official Method, 18th edition, Washington D.C. AOAC. 17th edn., official method 999.11 Determination of Lead, Cadmium, Copper, Iron and Zinc in Foods Atomic Absorption Spectrohotometry after Dry Ashing, 2000.

[21] T. Jang et al., Growth Characteristics and Physiological Functionality of Yeasts in Pear Marc Extracts, Mycobiology. 39(3) (2011) 170-173.

[22] A.P. Neal, T.R. Guilarte, Mechanisms of Heavy Metal Neurotoxicity: Lead and Manganese, Drug Metabolism and Toxicology. S5 (2012) 1-8.

[23] Codex Alimentarius Commission, "Revised Codex Standard for Honey Codex Stan Rev. 2 (2001)," Codex Standard, Vol. 12. (2001), pp. 1-7.

[24] FAO, Water quality for agriculture, R.S. Ayers, D.W. Westcot, FAO Irrigation and Drainage Paper 29, Rev. 1. FAO, Rome, 1985, 174 p.

[25] I.N.E. Onwurah et al., Integrated environmental biotechnology-oriented framework for solid waste management and control in Nigeria, International Journal of Environmental Waste Management. 1 (2006) 94-104.

[26] A.A. Adu, O.J. Aderinola, V. Kusemij, Assessment of Trace Metal Levels In Commonly Edible Vegetables From Selected Markets In Lagos State, Nigeria, Current World Environment. 9(3) (2014) 789-796

[27] O.O. Odukoya et al., Heavy metals in topsoil of Abeokuta dumpsites. Global J. Pure Applied Sci., 7 (2000) 467-472.

[28] O.A. Nubi et al., Impact assessment of dumpsite leachate on the qualities of surface water and sediment Of River Eku, Ona-Ara Local Government, Oyo State, Nigeria. Nigeria, Sci. World J. 3 (2008) 17-20.

[29] S.A. Uba, et al., Assessement of heavy metals bioavailability in dumpsites of Zaira Metropolis, Nigeria, African Journal of Biotechnology. 7 (2008) 122-130.

[30] N.E. Okoronkwo et al., Levels of toxic elements in soils of abandoned waste dumpsite, African Journal of Biotechnology. 5 (2006) 1241-1244.

[31] N.E. Okoronkwo et al., Risk and health implications of polluted soils for crop production, African Journal of Biotechnology. 4 (2005) 1521-1524.

[32] K. Ahmad et al., Determination Of Forage Concentrations Of Lead, Nickel And Chromium In Relation To The Requirements Of Grazing Ruminants In The Salt Range, Pakistan, Pakistan Journal of Botany. 4(1) (2009) 61-65.

[33] O.P. Sobukola, Heavy metal levels of some fruits and leafy vegetables from selected markets in Lagos, Nigeria, African Journal of Food Science. 4(2) (2010) 389-393.

[34] B.E. Chove, W.R. Ballegu, L.M. Chove, Copper and Lead levels in two popular leafy vegetables grown around Morogoro Municipality, Tanzania, Tanzania Health Research Bulletin. 8(1) (2006) 168-169.

[35] E. Enemari, Vehicular emissions: Environmental and health implications. National conference on the phase-out leaded gasoline in Nigeria, 2001.

[36] O.E. Orisakwe, Environmental pollution and blood lead levels in Nigeria: Who is unexposed, International Journal of Occupational and Environmental Health. 15(3) (2009) 315-317. 
[37] V.M. Thomas, A. Kwong, Ethanol as a lead replacement: Phasing out leaded gasoline in Africa. Energy Policy. 29 (2001) 1133-1143.

[38] R.N. Nwaoguikpe, The Effect of Crude Oil Spill on the Ascorbic Acid Content of Some Selected Vegetable Species: Spinacea oleraceae, Solanum melongena and Talinum triangulare in an Oil Polluted Soil, Pakistan Journal of Nutrition. 10(3) (2011) 274-281.

[39] FAO/WHO, Summary and conclusions of the seventy-third meeting of the Joint, 2010.

[40] WHO. (2011). Water-related diseases. Available at Geneva. Available: www.who.int/water_sanitation_health/diseases/arsenicosis/en/- accessed 22/09/201186.

[41] Codex Alimentarius Commissiom (CAC), Working Document For Information And Use In Discussions Related To Contaminants And Toxins In The GSCTFF (Prepared By Japan And The Netherlands). Joint FAO/WHO Food Standards Programme Codex Committee On Contaminants In Foods. 5th Session. The Hague, The Netherlands, 21 - 25 March, 2011.

[42] JECFA, Methylmercury, in: Safety evaluation of certain food additives and contaminants. Report of the 61st Joint FAO/WHO Expert Committee on Food Additives. Geneva, World Health Organization, International Programme on Chemical Safety. WHO Technical Report Series 922, 2004, pp. 132-139.

[43] A.P. Neal, Mechanisms of Heavy Metal Neurotoxicity: Lead and Manganese, Journal of Drug Metabolism and Toxicology. 5 (2012) 5-002.

[44] M.A. Radwan, A.K. Salama, Market basket survey for some heavy metals in Egyptian fruits and vegetables, Food and Chemical Toxicology. 44 (2006) 1273-1278.

[45] D.R. Buhler, C. Miranda, Antioxidant activities of flavonoids. OR, USA: Department of Environmental and Molecular Toxicology, Oregon State University, 2004. 